\title{
The bureaucratic distortion of academic work: a transdisciplinary analysis of the UK Research Excellence
} Framework in the age of neoliberalism

John P. O'Regan ${ }^{1}$ and John Gray ${ }^{2}$

Department of Culture, Communication and Media, UCL Institute of Education, University College London, 20 Bedford Way, London WC1H OAL, UK

\begin{abstract}
In the years since the second Thatcher government (1983-87), and continuing until the present, universities in the UK have been subjected to a series of neoliberal reforms which have had a deleterious effect on academics' working conditions and on the kind of research they are required to produce. 1986 saw the introduction of regular sector wide audits of research and scholarly activity designed to make academics more 'productive' and the institutions in which they worked more 'competitive'. This article takes as the object of its investigation the Research Excellence Framework (REF), the most recent iteration of the UK government sponsored assessment exercise. It adopts a transdisciplinary approach which draws on political economy, social theory and critical discourse analysis. The analysis exposes the ways in which the Research Excellence Framework constructs an illusion of intellectual excellence and innovation whose true purpose is the neutralization of the university as a centre of independent knowledge creation and learning, and hence as a potential locus of intellectual opposition to the neoliberal hegemony. The article concludes by calling on academics to refuse the narrow model of research valorized by the REF and to reclaim the idea of the university as a public good.
\end{abstract}

Desde los años del segundo gobierno de Thatcher (1983-87), y en continuación hasta el presente, las universidades británicas han sido sujetas a una serie de reformas neoliberales que han tenido un efecto perjudicial en las condiciones laborales de los profesores y en el tipo de investigación que tienen que producir. En 1986 se introdujo un proceso de evaluación gubernamental de la investigación en todo el sector universitario con el propósito de crear profesores universitarios más 'productivos' e instituciones más 'competitivas'. En este artículo tomamos como objeto de nuestra investigación el Ejercicio de la Excelencia de la Investigación que es el más reciente de las evaluaciones gubernamentales. Adoptamos un análisis transdisciplinario con raíces en la economía política, la teoría social y el análisis crítico del discurso. Nuestro análisis demuestra la manera en que este ejercicio construye una ilusión de la excelencia intelectual y de la innovación, el verdadero propósito del cual es la neutralización de la universidad como centro de creación del pensamiento independiente y el aprendizaje, y por lo tanto como un centro de oposición intelectual a la hegemonía neoliberal. El artículo concluye con una llamada a los profesores universitarios a rechazar el modelo de investigación valorizado por este ejercicio gubernamental y a reclamar la idea de la universidad como un bien público.

\footnotetext{
${ }^{1}$ CONTACT John O’Regan john.oregan@ucl.ac.uk
}

${ }^{2}$ CONTACT John Gray john.gray@ucl.ac.uk 
Key words: neoliberalism, UK higher education, Research Excellence Framework, critical realism, critical discourse analysis, semiosis

\section{Introduction}

This article has been written in the wake of transformative industrial action by members of the University and College Union (UCU) in Britain who went on strike for 14 days in the spring of 2018 to protest against Universities UK's (UUK) proposed changes to their pensions. In many ways the strike - which was spread over four weeks - and the level of support it achieved among staff and students came as a surprise to all concerned. UCU had previously been defeated in a series of badly organized campaigns over pay, membership had decreased as a result, and the chances of success at the outset seemed far from propitious. However, as the strike got underway it soon became evident that support was strong and that the proposed pension changes had acted as a catalyst for a range of other concerns. These included the casualized use of hourly paid lecturers to deliver, in some cases, up to 40 per cent of teaching, and the fact that almost 50 per cent of lecturers in the UK are estimated to have 'insecure' contracts (Bergfeld, 2018: 233); the marketization of British higher education generally; and the deleterious effects on teaching and research of neoliberal instruments of accountability such as the Teaching Excellence Framework (TEF) and the Research Excellence Framework (REF). Well-attended picket lines at campuses (including our own) across the country were characterized by open air 'teach-outs' which saw striking members of staff lead discussions with colleagues and students on the need to 'call time' on neoliberalism itself and (to borrow a metaphor from an earlier dystopian moment) bring an end to the 'polar night of icy darkness and hardness' (Weber ([1919] 1994: 368) ushered in by neoliberal reforms of higher education and the ensuing bureaucratic distortions of academic work.

In this article we focus on the REF as the UK sector prepares for the next assessment exercise due to take place in 2021. The REF has three dimensions of assessment: outputs, impact, and environment. Outputs refer to research produced by academics in the form of, for example, published research papers and books. These are graded by subject specialist panels in terms of their originality, significance and rigour. Impact, is defined broadly as the effect of the research on the economy or other aspects of society, i.e. 'beyond academia' (REF, 2014: 26). Environment refers to the vitality and sustainability of the institutional context within which the research takes place, and encompasses such things as doctoral completions and research grant income. These dimensions are graded and - crucially - funded on a measure of stars, from four star to one star respectively. We see the REF as a neoliberal economic mechanism designed to force institutions to compete for finite amounts of public money and as an instrument of neoliberal governmentality and subjectification (Foucault, [1982] 1988; [1978-79] 2008) designed to produce (paradoxically) docile yet highly individualistic academic workers. In keeping with the model of discourse analysis which we wish to apply in this article, our approach is a transdisciplinary one, drawing on political economy, social theory and critical discourse analysis (CDA) (see fuller discussion below). Political economy is understood as an activity which 'focuses on and analyses the relationship between the individual and society and between the market and the state, and [which] seeks to understand how social institutions, their activities and capitalism interrelate' (Block, 2017: 35). Our approach to CDA is a dialectical-relational one, and is derived from the more recent work of Fairclough (Fairclough, 2010, 2015; Fairclough, Jessop \& Sayer, [2004] 2010). Using a transdisciplinary theoretical and methodological 
perspective based on a dialectical-relational approach (DRA), in this article we analyze a selection of documents related to the UK Research Excellence Framework with a view to demonstrating how the discourse of the framework seeks to effect a particular neoliberalization of university practices in order to produce, and simultaneously place under surveillance, a certain kind of academic subject, while also presenting as given the neoliberal imaginary on which the REF is based. An intended effect, which neoliberal thinking 'encodes' into the REF (Hall, 1990) is the deliberate neutralization of the university as a centre of independent knowledge creation and learning, and hence as a potential locus of intellectual opposition to the dominance of the neoliberal hegemony. As part of this, we also document interdiscursive structural and textual selectivities and stratagems present in the discourse of the REF and subject these to critique. These include, inter alia, strategies and processes of recontextualization, givenness, technologization and the voiding of meaning, and ideological narrowing.

We begin by outlining our understanding of neoliberalism. We then present a short overview of the neoliberal reform of UK higher education and the evolving history of university research assessment exercises since the late 1970s, when the first overtly neoliberal British government under the leadership of Margaret Thatcher was elected. This is followed by a more detailed account of our theoretical perspective and methodological framework and approach, as well as a rationale for the documents selected as our 'semiotic point of entry' into the REF (Fairclough, 2010). Our analysis and discussion is followed by a short conclusion in which we argue, in line with Fairclough (2015: 15), that while 'CDA can inform action to change social life', it is only by becoming politically active, and 'through dialogue with social actors who are in a position to undertake such action', that academics can begin working towards the defeat of neoliberalism in higher education, and in society more generally.

\section{Neoliberalism}

It has been pointed out that neoliberalism is a 'variegated' phenomenon (Brenner, Peck \& Theodore, 2010), assuming different forms in national settings with diverse political, economic and cultural characteristics, as well as having evolved over time. However, despite this variegated nature, the term is generally used to refer to the forms of market fundamentalism which have characterized the current phase of capitalism since the late 1970s. Until now, neoliberalism has tended to favour unrestricted free trade (although protectionism has reappeared under Trump), the privatization of state assets, the dismantling of institutions associated with welfare statism (sometimes referred to as 'roll back' neoliberalism), the deregulation of financial markets, labour flexibility, and the marketization of areas of life which were previously outside the market (so-called 'roll out' neoliberalism). As well as favouring anti trade union legislation and low taxation of corporations, neoliberal regimes also tend to require a strong carceral apparatus to deal with the social problems it creates (Gottschalk, 2015; Wacquant, 2012). This is one of several ways in which the contradictory nature of neoliberalism is revealed. Despite generally being characterized by a rhetoric berating the notion of the intrusive state, neoliberal regimes rely on strong government to implement, monitor and ensure the smooth operation of neoliberal policy. In line with Marxist-influenced understandings of the term (Block, 2018; Brenner, Peck \& Theodore, 2010; Duménil \& Lévy, 2004; Harvey, 2005, 2010; Holborow, 2012; 2015), we take the view that neoliberalism is first and foremost 'a class project [...] [m]asked by a lot of rhetoric about individual freedom, liberty, personal responsibility and the virtues of 
privatization, the free market and free trade [...] designed to restore and consolidate capitalist class power' (Harvey, 2010: 10).

At the same time, neoliberalism is also an ideology, understand here in Marxist terms as a classbased representation of the world disseminated by the political, business, academic and media allies of capital as though it were common sense. Discursively (as we shall see in the analysis section) this has led to the vocabulary of the market being applied to more and more aspects of human activity (including the pursuit of knowledge and the related activities of teaching and learning) - a phenomenon which has been described as a process of 'semantic stretching' (Holborow, 2007). In terms of British higher education this has led to a discursive re-framing of academics and of their activity by means of the relentless deployment of 'an alien language' (Collini, 2012: 94) in which lecturers become service providers, students are recast as clients, courses are re-construed as products (with unique selling points) and academic scholarship and research is understood solely in terms of quantifiable ranked outputs (Fairclough, 2015).

All such changes, whether economic, ideological or discursive have the aim of producing a particular kind of subject - what Foucault (2008: 226) refers to as an updated version of the eighteenth century figure of homo economicus (see also Simpson, this issue), understood now as an 'entrepreneur of himself, being for himself his own capital, being for himself his own producer, being for himself the source of [his] earnings'. At the same time, this highly agentive late modern figure is characterized paradoxically as being 'eminently governable' (p. 270). In outlining the contradictions at the heart of the neoliberal homo economicus, Foucault is drawing on Becker's ([1964] 1993) concept of personhood, whereby the individual is understood reductively as the embodiment of a 'bundle of skills' comprising his or her 'human capital' and typified by a high degree of what we term responsive plasticity. On this view homo economicus is 'the person who accepts reality or who responds systematically to modifications in the variables of the environment' (Foucault, 2008: 270; our emphasis). Thus it would seem that it is the agility of homo economicus to respond to the changes and requirements of the economy that is the source of his or her (dubious in our view) entrepreneurial freedom. However, the production of such a subject can be seen as integral to the neoliberal project and one of the reasons why education systems globally (from primary through to tertiary level) are so important for neoliberal governments. As we shall see, ideas such as these and the semantic 'stretching' which accompanies them permeate the specific practice and the discourse of the REF, the analysis of which forms the second half of this article.

\section{The 'reform' of British Higher Education}

Prior to the election of the first Thatcher government in 1979, British universities had been funded largely for much of the twentieth century by an annual government grant distributed by the University Grants Committee (UGC), thereby keeping government to some extent at arm's length. As the number of universities grew and the number of students attending them increased, particularly in the period following second world war, the amount of public money needed to finance them increased. From the perspective of the newly elected Conservative government in 1979, ideologically committed to extending the range of the market, such institutions were perceived to be 'expensive, self-absorbed, arrogant, and subversive' (Collini, 2012: 33) and in need of reform. In what was to be the first step in a process of near permanent interference (lasting nearly 40 years at the time of writing), the annual grant was slashed by $11 \%$ in 1981 , causing shock waves across the sector. Then in 1986 the second Thatcher government, buoyed up by the 
defeat of the miners' union (following a bitterly-fought strike) and a wave of state industry privatization, embarked on a more thorough reform of higher education in ways which were to have a dramatic effect not only on the working lives of academics, but also on the nature of academic freedom, the valorization of academic activity, and the very concept of knowledge itself (Collini, 2012, 2017; Cook 2012; Warner, 2015). This year saw the introduction of the first of a series of research assessment exercises - sector wide audits of academic work - which were ostensibly designed to make academics accountable to market strictures and determine how much government money would be allocated to the institutions which employed them. Such exercises have come to play a key role in the hiring of staff and feed directly into the creation of league tables, which institutions in turn use to promote themselves.

At the time of writing, the scope and nature of REF 2021 is being prepared in the light of the Stern Review (2016) which evaluated the 2014 exercise. Saturated, as we show below, with the alien language described by Collini, the report makes for characteristically incoherent reading, particularly with regard to the unforeseen consequences of the REF. The Stern Review identifies a number of 'distortions' and 'burdens'. These include the rising cost of assessment exercises (which necessarily entail mock assessments and in many cases the hiring of external consultants) - for example the cost of the 2014 REF was $£ 246$ million, an estimated 133 per cent more than the cost of the 2008 assessment. Paradoxically, 'gaming' the system is also identified as a problem, when it is clear that the system itself is a high stakes game, and regarded as such by institutions desperate for a good REF submission. The report identifies the recruitment of key researchers close to the REF census date as 'an unhelpful driver of asymmetric salary inflation, as institutions compete to attract and retain key individuals' (Stern, 2016: 12). Further 'distortions' are the effects on research itself, with safe topics, short-termism and an avoidance of 'risky or multidisciplinary projects' (p.14) being the preferred choice for REF evaluation. Other consultative reports on the 2014 REF, noted the negative effect of the assessment on staff morale and wellbeing, given that only certain kinds of work were valorized, and that participation in the assessment is (contrary to claims otherwise) linked directly to career prospects (Technopolis, 2016). However, despite such feedback from those involved, and despite the growing body of scholarly critique (Collini, 2012, 2017; Cook, 2012; Holmwood, Hickey, Cohen \& Wallis, 2016; Sayer, 2015; Warner, 2014, 2015), the UK government continues to endorse such assessment exercises for reasons which are clearly ideological and almost entirely related to the imposition of control.

\section{Theoretical and methodological considerations}

In this section we present a summary overview of the theoretical and methodological considerations which have informed the selection and analysis of the REF documents which are referenced in this study (see below). In the following paragraphs we elaborate a transdisciplinary approach to textual analysis which builds upon and extends the political economy perspectives already developed in the first part of this article.

The diffusion of neoliberalism as an economic and ideological orthodoxy has been well documented and widely critiqued in studies in political economy and social theory (Boltanski \& Chiapello, 2006; Bourdieu, 1998; Crouch, 2011; Dardot \& Leval, 2013; Duménil \& Lévy, 2013; Hall, Massey \& Rustin, 2013; Harvey, 2005, 2014; Mirowski, 2013; Panitch \& Gindin, 2011; Peck, 2010; Stedman-Jones, 2012). It has also been documented and critiqued in applied linguistics and its associated domains, which have in turn often drawn on the aforementioned fields and scholars for their critiques (Block, Gray \& Holborow, 2012; Chun, 
2017; Holborow, 2015; Phillipson, 2008). One of the earliest critiques from the social theory side is found in Foucault ([1978-79] 2008) whose precise interests, as we have seen, are the subjection of the individual to neoliberalism and the individualist subjectivity of homo economicus. Fairclough (2005), from the twin perspectives of governance theory and critical realism, utilizes the conception of imaginaries in the context of a discussion of European Union education policy to describe how apparently self-evident constructs, such as 'the European education space' and the 'competitive knowledge based economy' are 'scaffolded into existence and sedimented into institutions and operative networks as material practices' (Robertson, 2002, cited in Fairclough, 2005: 57). Crucial to the processes of imagining and scaffolding is the mind-numbing incessancy with which stock phrases and nostrums are repeated and reproduced in the discourse, such that the collective consciousness is effectively 'bludgeoned' into acceptance of them. In the words of Robertson, '[They] embed a particular kind of framework for action, a particular type of commonsense' (cited in Fairclough, ibid: 57). Very similar processes are in evidence within the UK REF. Here too there is incessant repetition of favoured neoliberal wordings and conceptions, such as 'the need for excellence', 'fostering excellence', 'accountability and information', 'benchmarking', 'driving competition', 'quality related research funding', 'commercialization', 'research base', 'impact as a principle', 'competitive pressure', 'reach and significance', 'transparency', and so on. As Fairclough is at pains to point out, such categories are 'not self-evident entities' (ibid: 56), but are socially constructed, and inasmuch as they are also written and spoken about in texts of various kinds, they are also in part semiotic ones too. This has the corollary that social and political institutions as a result of the texts (and practices) which they produce are also partly semiotic, and so are open to semiotic analysis and critique. This explains our focus on the UK REF as both an order of discourse (i.e. a social assemblage or institution in its semiotic aspect), and as a specifically neoliberal form of governance and surveillance. The peculiar modalities of the REF are operationalized in British higher education in the form of a dialectical relation between discourses (ways of construing the world), genres (ways of acting and interacting), and styles (ways of being) (Fairclough, Jessop \& Sayer, [2004] 2010; O'Regan \& Betzel, 2016; Zotzmann \& O'Regan, 2016). Changes in discourses, genres and styles, as a result of internal or external dialectical stimuli, may lead to the emergence of new beliefs, new practices and new identities. Once these coalesce into new assemblages, the result may be the reconfiguration of an existing order of discourse, or possibly, in time, the emergence of a new one (i.e. through a new configuration of discourses, genres and styles). Discourses may thus be causally efficacious. That is, they can have causal effects (Bhaskar, 2016).

\section{The framework of analysis}

Let us now turn to the general framework for the analysis. As mentioned in the introduction, in this article we adopt a dialectical-relational approach. The dialectical relational approach (DRA) is dedicated to analysis of the discourse practices which constitute social institutions and structures in their semiotic dimension. From the perspective of social theory, the DRA is informed by a critical realist social ontology (Bhaskar, $1986,2008,2016)$, whereby the social world is understood as stratified and differentiated, and in which the concepts of the 'the real' (i.e. that which exists - whether materially or institutionally - and is potentially causally efficacious), 'the actual' (i.e. what happens when the generative potentialities of the real are operationalized or become agentive) and 'the empirical' (i.e. the ways in which these are experienced or understood by actors) are central. For the purposes of its methodology, the DRA matches the causal 
dimensions of the real, the actual and the empirical to discourse and texts. The real, the actual, and the empirical are 'overlapping domains of reality' (Bhaskar, 2008: 56) which in critical realism correspond to social structures, social practices, and social events. The three levels are not discrete, but are intersecting and dialectical. We may render this relation as real > actual > empirical. Each of these levels also has a corresponding semiotic dimension which we can present as semiotic systems > orders of discourse > texts. In this latter formulation, 'texts', whether written, spoken, or realized in other semiotic modes, are components of both the actual and the empirical, as different discourse practices emerge in texts and are interpreted by individuals and groups. The relationship between the different levels is understood as dialectical, and as part of a 'dialectics of discourse' in which discourse is one 'moment' amongst many, with no particular moment dominating (Fairclough 2010; Fairclough, Jessop \& Sayer, [2004] 2010; Harvey, 1996). As discourse analysts we may apply these distinctions to semiosis and then to procedures of discourse analysis in the following way:

$\mathrm{s}_{1}$ semiosis/discourse at the level of the real;

$s_{2}$ texts at the level of actual; and

$\mathrm{s}_{3}$ interpretation of texts at the level of the empirical.

(Based on Bhaskar, 2016: 103)

The discourse analysis of texts is therefore an aspect of $s_{2}$ and $s_{3}$, by means of which orders of discourse are examined and texts analyzed and interpreted. The analysis of texts constitutes a semiotic point of entry into the object of the research as a semiotic assemblage of assumptions, practices and identities (i.e. discourses, genres and styles) which have been interdiscursively 'textured' into the text. The DRA of Fairclough (2010) suggests a model of 'explanatory critique' which is derived from Bhaskar (1986, $2008,2016)$. The framework below is an adaptation of this.

Stage 1: Focus upon a social phenomenon in its semiotic aspect (Draw upon relevant theory and look for a semiotic point of entry)

a. Step 1 Identify the phenomenon to be researched.

b. Step 2 Use relevant theory to theorize the phenomenon in a transdisciplinary way (e.g. by combining and internalizing conceptual categories from different fields or disciplines). Look for a semiotic point of entry.

Stage 2: Identify the causes of the phenomenon and the obstacles to changing it (Ask why the phenomenon is the way that it is)

a. Step 1 Select texts in the light of the object of research and adopt a framework of analysis.

b. Step 2 Analyze relevant texts. Link linguistic analysis to interdiscursive and social analysis.

Stage 3: Does the social order require the phenomenon to be the way that it is?

Stage 4: Identify ways past the obstacles. How might the dominant discourse be contested?

(Based on Bhaskar, 2016; Fairclough, 2010; O’Regan \& Betzel, 2016) 
Stage 1 has been developed in the first part of this article and above. We are now at Stage 2 and the selection and analysis of relevant texts as a means of examining and critiquing the REF. Stages 3 and 4 are addressed in the conclusion. Our semiotic point of entry into the REF is the official documentation which has been published about it, which in its entirety is to be found online. We estimate that governmentsponsored online material on the REF extends to hundreds of thousands of pages and many millions of words. The vastness of the documentation has required that we be selective, and so we decided to focus our analysis on five key documents within the recent chronology of the REF, and which were published in the period 2011-2017. They therefore cross the timeframe of the last REF in 2014 and are the key preparatory documents which are presently guiding the implementation of the next REF in 2021. The principal documents which we selected as a basis for our analysis were the following:

\section{$\mathrm{D}_{1}$ : Assessment Framework and Guidance on Submissions (REF 2014; REF 02.2011)}

$\mathrm{D}_{2}$ : Panel Criteria and Working Methods (REF 2014; REF 01.2012)

$\mathrm{D}_{3}$ : Building on Success and Learning from Experience: An Independent Review of the Research Excellence Framework. (Lord Nicholas Stern, July 2016)

$D_{4}$ : Consultation on the Second Research Excellence Framework (HEFCE, December 2016/36)

$D_{5}$ : Initial Decisions on the Research Excellence Framework 2021 (REF 2021; REF 2017/01)

The subject matter of these documents is, we hope, self-evident from their titles. Suffice to say, $D_{1}$ is concerned with how academic submissions to the UK REF are to be assessed by panels of subject experts, who have put themselves forward for the job and been approved. $D_{2}$, the text itself declares, 'should therefore be read alongside REF 02.2011' $\left(D_{2}: 1\right)$. And in $D_{1}$, a similar statement is made that the reader should 'refer to the documents setting out the panel criteria and working methods of the four main panels' $\left(D_{1}: 3\right)$, namely in $D_{2}$. In the present REF cycle, documents $D_{1}$ and $D_{2}$ are due to be republished with some minor modifications in 2019 in time to guide the next REF assessment in 2021. The present documents $\left(D_{1}\right.$ and $D_{2}$ ) are therefore the ones which were applied to the last REF in 2014. Documents $D_{3}, D_{4}$ and $D_{5}$ have all been published since that time. $D_{3}$ is the 'Stern Review'. The review has been influential in guiding the particular formulation which is to be applied to REF 2021. This will involve some minor adjustments to the guidance for REF 2021, which will be incorporated into the 2019 iterations of $D_{1}$ and $D_{2}$. Otherwise these documents will be largely identical to those which were applied to REF 2014. Hence their inclusion in this study. $D_{4}$ sets out the proposals of the four UK higher education funding bodies for REF 2021. It was published under the auspices the Higher Education Funding Council for England (HEFCE). Finally, $D_{5}$ comprises the initial decisions on REF 2021 which have been reached as a consequence of the Stern Review, and which will inform the reiterations of $D_{1}$ and $D_{2}$ when they are republished, as seems likely, in 2019. Let us now turn to the analysis and discussion of the texts.

\section{The UK Research Excellence Framework: a critical discourse analysis}

Due to the limitations of space, our approach has been to identify examples of characteristic discourse features and themes within the texts, which are representative of the REF as an order of discourse and as a particularly neoliberal configuration of discourses, genres and styles. As mentioned in the introduction, 
these include processes of recontextualization, givenness, technologization and the voiding of meaning, and ideological narrowing. These and related concepts will be expanded upon as we proceed.

\section{(i) Recontextualization}

To begin with, recontextualization refers to the process by which the language elements of one social domain are able to colonize, or have been appropriated by, another social domain (Bernstein, 1990; Chouliaraki \& Fairclough, 1999; Fairclough, 2012). The REF, which is in the domain of education, is not surprisingly characteristic for the manner in which the language of business and accounting has been incorporated and operationalized within it. Excerpts $A 1$ to $A 4$ are examples of this.

A1 The assessment provides accountability for public investment in research and produces evidence of the benefits of this investment $\left(D_{1}: 4\right)$.

A2 to provide benchmarking information and establish reputational yardsticks, for use within the HE sector and for public information. $\left(D_{4}: 4\right)$

A3 Professional evaluations of exhibitions, performances or other outputs. Formal peer reviews of funded impact-relevant research. Studies on the social return on investment. $\left(D_{2}: 91\right)$

A4 an assessment of quality of research is vital, not only to enable the efficient distribution of QR funding, but also for benchmarking, accountability and to support strategic decision making $\left(D_{3}: 18\right)$

This kind of discourse, with its emphasis on accountability, investment, social returns, funding, benchmarking and impact, is not unexpected, since the purpose of the REF is to bring neoliberal market principles to bear upon academic research. Our point, however, is that it has become a naturalized feature of government discussions of higher education that university activities should be presented in this way, and that this discourse has been, to borrow the words of Robertson (2002), 'scaffolded' and 'sedimented' into the REF as a matter of common sense. Recontextualization is therefore a significant nodal point, or 'moment', for the construction of the operational networks and practices of the REF, as well as for the universities and academics at which it is directed.

\section{(ii) Givenness}

Closely related to processes of recontextualization is the notion of 'givenness', or the unspoken acceptance of discursive constructions of the real. This in turn leads to epistemological reductionism, and the epistemic fallacy 'that statements about being can be reduced to or analysed in terms of statements about knowledge' (Bhaskar, 2008: 36). That is to say, rather than describing the world, the description itself becomes the world. From a discourse perspective, givenness may be understood as a category which is discursively presupposed, or 'imagined'. What is taken as given can be stated, as an open statement of fact for example, or it may be implied or unconsciously assumed (e.g. as an ideational category). There are many kinds of givens in the texts, for example to do with why the REF exists, the 'need' for the assessment of research, the requirement of 'transparency' concerning how research is graded, the importance of 'maintaining research excellence', and so on. Together these represent a network of discursive relations against which the real is absented and the actual is set in its place. This is to suggest therefore that 
neoliberalism, is based upon false or imaginary assumptions about the real which are then presented in its texts as givens.

The aspect which most interests us in the present context is how texts $D_{1}$ to $D_{5}$ display an unquestioning acceptance of the neoliberal imaginary concerning 'value', and of what Marx called the 'the silent compulsion of economic relations' ([1867] 1976: 899), in this case of neoliberal relations. This given is in part established in the texts by recontextualization, but it is also ideological, in the twin senses of interpellation and the hegemonic construction of 'spontaneous consent', which is present throughout the texts (Althusser, 1971; Gramsci, 1971: 12). This occurs, for example, through the givenness of the concept of impact on the 'imagined' neoliberal economy as fundamental to the research activity of academics and the universities to which they belong, and to which they are unquestioningly expected to consent.

B1 The sub-panels will assess the 'reach and significance' of impacts on the economy, society and/or culture that were underpinned by excellent research conducted in the submitted unit, as well as the submitted unit's approach to enabling impact from its research. ( $D_{1}: 8$; our italics)

B2 For the purposes of the REF, impact is defined as an effect on, change or benefit to the economy, society, culture, public policy or services, health, the environment or quality of life, beyond academia. ( $\mathrm{D}_{1}$ : 26; our italics)

B3 Impacts on research or the advancement of academic knowledge within the higher education sector (whether in the UK or internationally) are excluded. ( $D_{1}$ : 26-27; original emphasis)

B4 HEls are reminded that impacts on research or the advancement of academic knowledge within the HE sector (whether in the UK or internationally) are excluded $\left(D_{2}: 48\right.$; original emphasis)

B5 Finding ways to ensure that the REF can encourage researchers to explore big or fundamental problems, in ways that may not deliver a steady stream of papers or a quick monograph; to deliver academically excellent synthesis of evidence and meta-analysis to support policy making; and to develop game changing ideas that, for example, can lead to the development of new disciplines, or that have significant impact outside their discipline, is a priority. $\left(\mathrm{D}_{3}\right.$ : 10 ; our italics)

The Stern Review $\left(D_{3}\right)$ states as a matter of fact that it is 'in all academics' interests to be able to indicate the impact of the research that they undertake' $\left(D_{3}: 22\right)$, but without in any way specifying what this actually means, or what kinds of interests it serves. Rather, this is presented as given, with the consequence that the 'real' interests of academics, i.e. their real motivations for being in higher education and doing the work that they do, are obfuscated away in favour of an interpretation which suggests that the very legitimacy of being an academic in a UK university rests on being able to demonstrate how one's research 'impacts' upon the neoliberal economic imaginary. This is representative of a 'discursive shift' which has occurred over the past nearly 40 years in the UK as to the 'proper' function of universities in modern liberal democracies, and whose emergence can be tracked, in part, via the discourse of the REF. In excerpt B1 above, for example, the nominal phrase 'reach and significance' presents simultaneously the sense of movement to a distance and of maximal change occurring once there. B2 makes the sense of movement still more explicit with its definition of impact as only applying 'beyond academia' and not within it. Excerpts B3 and B4 take this 
further in order to state, again as a matter of fact, that impacts on research or the advancement of academic knowledge within the university sector are specifically 'excluded' (often rendered in boldface) from consideration. This can also be seen from excerpt B5, which is from the Stern Review, where the emphasis is clearly on impact outside the academy as being 'a priority'. Due to semantic selectivity in the composition of the REF texts, and of which these excerpts are examples, not only is the university practice of academics disvalued, but value is only conferred upon work which can be counted as being in some way demonstrably external to that community. It is in this manner that the umbilical linkage of academic practice to the imaginary of a neoliberal economy (and what constitutes value in such an economy) is established.

\section{(iii) Technologization and the 'voiding' of meaning}

In an early article on neoliberalism in UK higher education, Fairclough (1993) refers to the technologization of discourse 'as the constitution of expert systems whose domain is the discursive practices of, particularly, public institutions' (p. 141). He characterizes this as largely being in the form of the 'top-down imposition of new discursive practices by organizations upon their members' (ibid.). 'Impact' and the pursuit of 'excellence wherever it may be found' $\left(D_{3}: 7\right)$ would be examples of the technologization of discourse in this sense. Indeed, the whole of the REF is an example of this. The REF, and injunctions around such things as 'excellence' and 'impact', set up systemic expectations around what are considered to be the appropriate behaviours and subjectivities to adopt which will fulfil the outcomes that the formulators of the system wish to achieve. Associated with technologization of this kind in the REF is the use of a 'technicist' vocabulary and rhetoric for describing the procedures which are to be followed and the regulations which are to apply. Their principal effect is often to 'empty' the text of meaning, through the widespread employment of 'catch-all' nominal phrases (e.g. 'excellence', 'impact', 'environment', 'burden', 'research base', 'reach' etc.), all of which come together in the texts as a profound technicist opacity and obfuscation.

C1 In developing our proposals, we have been mindful of the level of burden indicated, and have identified where certain options may offer a more deregulated approach than in the previous framework. We do not intend to introduce new aspects to the assessment framework that will increase burden. ( $D_{4}: 4$; our italics)

C2 We will continue to weigh the burden on institutions against the need to ensure accountability in disbursing public funds. ( $D_{1}: 5$; our italics)

C3 Focussing QR funding on excellence should, in large measure, be based on strong evidence of excellence in past performance. ( $D_{3}: 6$; our italics)

C4 Higher Education institutions will and should have strategies for shaping their research endeavour and recognising excellence ( $D_{3}$ : 12; our italics)

C5 The funding bodies' shared policy aim for research assessment is to secure the continuation of a world-class, dynamic and responsive research base across the full academic spectrum within UK higher education. ( $D_{5}: 4$; our italics)

C6 The research environment will be assessed in terms of its 'vitality and sustainability'. Panels will consider both the 'vitality and sustainability' of the submitted unit, and its contribution to the 'vitality and sustainability' of the wider research base ( $D_{1}$ : 44 ; our italics) 
We do not have the space to go into a detailed analysis of the many catch-all wordings and phrasings in REF texts, but for us the key point is that it is often not at all 'transparent' what these wordings mean. Indeed, some of them are so vague as to be almost meaningless, or more to the point, they are so meaningless that they can be made to mean anything. At first sight, it might appear that the preoccupation with reducing 'burden' which is mentioned on multiple occasions across the texts (e.g. in excerpts C1 and C2 above), concerns or at least includes burdens placed on academics in terms of the massive demands and pressures which the REF imposes upon them to meet its assessment requirements. Closer inspection, however, reveals that the noun 'burden' is only used in the texts in relation to the institutional and organizational 'costs' of fulfilling the assessment, and never in relation to the burdens which it places on academics, whom we have already established are unquestioningly obliged to comply regardless. This then is a selective or partial referencing of 'burden' such that across all of the texts the notion of burden is 'economized'.

It will be recalled that the ' $E$ ' in REF refers to 'excellence' and that the exercise is 'obviously' about things being 'excellent' in some way, and inasmuch as the reader can be relied upon to know or intuit this, the meaning of excellence is supposedly transparent, as in excerpts $C_{3}$ and $C_{4}$ above. Analysis of the wider REF texts as a whole reveals that this is the principal manner in which the reader is meant to understand 'excellence' in the REF. There are, as mentioned earlier, the gradings from four star to one star across the different quality sub-profiles for outputs, impact and environment to refer to, but none of the criteria there give a definition of 'excellence'. These only mention 'quality', as for example in the following gloss of 'four star' as meaning 'Quality that is world-leading in terms of originality, significance and rigour' ( $\left.D_{1}: 43\right)$. Excellence therefore remains unexplicated in any 'meaningful' way. Our feeling is that this is very much a deliberate semantic stratagem within the discourse, in addition to being a characteristic feature of it. That is, the use of all-encompassing terms which have superficial resonance but whose proper meanings are sufficiently vague and obscure that they can be manipulated to mean anything their users desire. The references to the 'research base' in excerpts $\mathrm{C} 5$ and $\mathrm{C} 6$ are another point in fact. Obvious and yet obscure, transparent and yet opaque, the 'research base' appears as both something and nothing simultaneously. In this article the manner in which texts are emptied or 'voided' of meaning in this way is what we mean by technologization. Closely associated with voiding are the technicist rhetorical constructions which are employed at several places in many of the texts, and which often make them dense and difficult to read. Here is an example.

C7 The REF panels will form an environment sub-profile by assessing the information submitted in REF5 (the environment template), informed by the data submitted in $\mathrm{REF} 4 \mathrm{a} / \mathrm{b} / \mathrm{c}$, as described in this section. When we provide submissions to sub-panels, we will supply a standard analysis of the quantitative data submitted in REF4a/b/c, in respect of each submission in that UOA, and aggregated for all submissions in that UOA, as listed in Annex $\mathrm{H}$. Panels will consider these data within the context of the information provided in REF5, and within the context of the disciplines concerned. Panels' criteria statements will indicate how the data analyses will be used in informing the assessment of the research environment. $\left(D_{1}: 30\right)$

This excerpt relies on a complexity of input from diverse text-internal and intertextual sources for their meaning. The volume of information which is packed into each clause heightens the opacity of paragraph, and makes for difficult reading. It is also necessary to cross reference to other sections in the same 
document, for which no signposts are provided, and from there to a range of other documents which are signified as REF5, REF4a/b/c, and Annex H. What appear in $\mathrm{C7}$ as active clauses and therefore as simple matters of visible agents acting upon verbs are made more complex since a number of the agents are inanimate rather than human (e.g. 'REF panels', 'Panels', 'Panels' criteria statements'). This also adds to the processing density of the paragraph. Indeed, to gain a fuller command of this paragraph requires the accumulation of considerable additional procedural REF information and documentation, such that this one paragraph can be said to represent a 'condensation' and 'simplification' (Fairclough, 2005) of a multitude of other texts and associated procedures. In the light of such density we are reminded of Marx's comment about ideas that form in the heads of capitalists 'about the laws of production that diverge completely from these laws and are merely the expression in consciousness of the apparent movement' (Marx, 1991 [1894]: 428). Just as capitalists do not understand the inner movement of capitalism and focus on the apparent, or surface, movement instead (the epistemic fallacy again), so too is it an apt description of what is occurring in processes of technologization in the REF, and of how neoliberal imaginaries effect this. The result is enormous opacity and obfuscation, in which the texts in their efforts to reproduce the imaginary, permit meaning to fall away and for a studied vacuity to take its place.

\section{(iv) Ideological narrowing}

By ideological narrowing we refer to the process by which the meanings of key REF concepts, such as 'research' and 'impact' are 'narrowed' and selectively presented in the texts. Since we have already devoted a good deal of space to the discussion of 'impact', in this section we will focus on the meaning of 'research' in the REF. It is our contention that in the REF the meaning of research is narrowed to such an extent that it devalues and even excludes research activity which is in any way contemplative or not based on the collection of empirical data. By this we mean work which might be described as largely historical, philosophical, literary, artistic, linguistic, cultural, or even political, although this is not meant to be an exhaustive list. This is also despite statements to the contrary. The following statements appear in the REF guidance document (text $D_{1}$ ).

E1 The REF aims to assess all types of research without distorting the activity that it measures or encouraging or discouraging any particular type of research activity, other than providing a general stimulus to enhancing the overall achievements of the UK research base. ( $D_{1}: 4-5$; our italics)

E2 [Research] includes work of direct relevance to the needs of commerce, industry, and to the public and voluntary sectors; scholarship; the invention and generation of ideas, images, performances, artefacts including design, where these lead to new or substantially improved insights; and the use of existing knowledge in experimental development to produce new or substantially improved materials, devices, products and processes, including design and construction. ( $\left.D_{1}: 48\right)$

Between E1 and E2 there is an evident intratextual disjuncture and tension, since the definition in E2 quite clearly favours an interpretation of research which is heavily weighted towards activities that are considered to have the potential to benefit the economy. This tension is also evident in E2 itself. The 'needs' of commerce and industry are not unexpectedly placed first, with direct relevance to 'the public and voluntary sectors; scholarship; the invention and generation of ideas, images, performances, artefacts including 
design' being rather uncomfortably sandwiched between 'experimental development to produce new or substantially improved materials, devices, products and processes, including design and construction'. The principal emphasis thus seems to be clearly economic and this has the effect of transferring this sense to the definition as it is presented as a whole, with the effect that scholarship which engages in matters which have no direct relevance for the economy are consequently disvalued. This semantic disjuncture thus contradicts the statement in E1 that 'The REF aims to assess all types of research without distorting the activity that it measures or encouraging or discouraging any particular type of research activity'. The definition in $\mathrm{E} 2$ is a good example of ideological narrowing, because as a result of its construction not only are all types of research not equally valued, but the research activities it describes are also inevitably distorted by it.

The tension which exists in the REF concerning what kinds of research are truly valued is further evidenced in statements of the following kind.

E3 Each individual HEI determines how best to use its allocated funding, allowing it to plan strategically for the long term, to sustain researchers between project grants, and to develop and respond quickly to emerging new areas of research. ( $D_{1}: 4-5$; our italics)

E4 Finding ways to ensure that the REF can encourage researchers to explore big or fundamental problems, in ways that may not deliver a steady stream of papers or a quick monograph; to deliver academically excellent synthesis of evidence and meta-analysis to support policy making; and to develop game changing ideas that, for example, can lead to the development of new disciplines, or that have significant impact outside their discipline, is a priority. ( $D_{3}: 14$; our italics)

E5 Finally we stress the centrality of research to the future of the UK. Measured by the fraction of GDP (both public and private) we underinvest in research and innovation relative to our comparators in advanced countries. ( $D_{3}: 35$; italics in the original)

E6 The Stern review underlined 'the essential role of interdisciplinary research in addressing complex problems and research questions posed by global social, economic, ecological and political challenges' ( $D_{5}$ : 5; our italics)

Excerpt E3 presents a conception of research which is based not simply on funding, but the assumption that to be a researcher is to be externally funded, which is not the basis on which the vast majority of researchers in UK universities do their research. In addition, being able 'to develop and respond quickly to emerging new areas of research' suggests a strong 'science' bias that does not readily resonate with research in the arts and humanities and a good deal of the social sciences. Excerpts E4, E5 and E6, which are from texts $D_{3}$ and $D_{5}$, reinforce this impression. E4 places emphasis on research into 'big or fundamental problems' and which will 'support policy making'. In addition, it borrows from business the phrase 'game changing ideas' which strongly implies research which is based on making 'innovations' which may change the world, and which presumably the UK can use to gain a competitive edge in the global economy. A philosophical treatise on, for example, the contradictions contained in Hume's Law, or a research article on kinship in Beowulf, struggle to find meaningful purchase within a discourse which constantly belabours, in the words of excerpt E6, 'research questions posed by global social, economic, ecological and political challenges'. That goes for the present article as well. The consequence of this is widespread selfcontradiction within the texts of the REF, while also persistently foregrounding a much narrower view of 
research than is claimed. Overall, the foregoing analysis across the discourse dimensions which we have identified reveals the REF to be a partial and highly selective web of systemic surveillance and control, whose principal purpose is to silence the university as a locus of critique and to bend it to the neoliberal imaginary.

\section{Conclusion}

The model of explanatory critique which has been presented in this article asks, at Stages 3 and 4, whether the social order requires the phenomenon to be the way that it is, and what the options are for reform and/or resistance. In Bhaskar's words, this aspect of explanatory critique 'looks for hitherto unrealised possibilities for change in the way life is currently organised' (2016: 109). There seems no doubt that in respect of the current situation in the UK and elsewhere, it is essential to the neoliberal 'multiverse' that the imaginary which underlies the REF and the UK government's attitude to higher education is sustained. UK higher education under the REF is to be the object of unceasing technocratic intervention and reinforcement as the texts which we have analyzed show. At the present time, the REF operates according to a seven year cycle between assessment points during which time academic, managerial and administrative staff are being required to 'regiment' themselves to its demands. Daily life in the university has been affected to such an extent that the REF has come to consume the lives of those who work in them. To this regime is soon to be added the TEF with which to stifle the university further by adding still greater technocratic complexity and communicative dysfunction to an already deeply complex and communicatively dysfunctional system. The Scylla and Charybdis of the REF and the TEF thus stand in fundamental contradiction with Hayek's promise of the market as a locus for the 'spontaneous forces found in a free society' (Hayek, [1944] 2001: 21), as there is nothing which is spontaneous or free about either of them. Rather, in an act of spectacular self-contradiction, neoliberalism and its supporters 'have in effect undertaken to dispense with the forces which produced unforeseen results [i.e. a free society] and to replace the impersonal and anonymous mechanism of the market by collective and "conscious" direction of all social forces to deliberately chosen goals' (Hayek, ibid.). This appears as an hypocrisy, which of course it is. But it is one which our analysis shows is hidden in plain view and is essential to a neoliberalism which eulogizes 'freedom' while seeking to govern society from within a Weberian 'iron cage'. In its semiotic aspect, we have seen how the instrumental rationality of the REF consists in a configuration of discourses, genres and styles concerning the economization of the social world, the modality of institutional and individual interactions with the REF as an order of discourse, and the subjectivities which academics and those with oversight of academics are expected to adopt. We must conclude then, that according to the terms of explanatory critique, the social order does need the phenomenon to be the way that it is.

We are under no illusions that moving beyond the obstacles which neoliberalism, through the REF, has created for research in UK higher education is no easy matter, although we have been heartened by the recent industrial action with which we opened this article, and this is certainly something to build upon. Explanatory critique suggests that the realization of possibilities for change requires an 'emancipatory practice oriented to the definitive resolution of the social problem or ill' (Bhaskar, 2016: 109). This involves 'concrete utopias', or the setting of interim goals, in addition to 'a theory of transition, and a relationship to an on-going depth struggle' (ibid.). Our medium-term objective for higher education in the UK would be the dismantling of the REF (and the TEF), and the reinstitution of the university as a centre for the acquisition 
and dissemination of knowledge, and for the holding of the state and its institutions to account. In other words, the reconstitution of the university as a public good rather than a private one. In contradistinction to the neoliberal educational imaginary assumed by the Stern Review and the related texts of this study, we propose a resolute and vocal resistance, which consists, in part, of continuing to research and write in ways which are meaningful for ourselves as academics, rather than in ways which are supposedly meaningful for the REF. Only in this way can we immediately take a stand against the ongoing degradation of the university and of the lives of its employees. Further, we must openly challenge within our institutions, as well as in the act of producing the work that we publish, the very assumptions upon which the REF is based, and we must seek alliances with others in the public sphere who also wish for an end to the neoliberal immiserization of human wellbeing. As a first step in the formulation of a concrete utopia for our resistance, we must seek to produce work which is for the good of the academy and for the good of society at large, rather than for the grossly-distorted imaginary which is presupposed by the REF. We do this by being active researchers and critics in the free and open pursuit of knowledge and learning, and by 'the elaboration and defence of the public interest' (Bourdieu, 1998: 5). This is our obligation to ourselves and to the generations who come after us, in universities and outside them, for the REF is the construction of unfreedom amongst the free, and we call upon our colleagues to resist its hegemony by every reasonable means.

\section{Notes on contributors}

John P. O'Regan is Reader in Applied Linguistics at UCL Institute of Education, University College London. He specializes in English as a global language, intercultural communication, and critical discourse analysis, and is the author of articles on a wide range of topics in cultural studies and applied linguistics. He has published in several journals, including the Journal of Applied Linguistics, Language and Intercultural Communication, Critical Discourse Studies, and the Journal of the Royal Asiatic Society Hong Kong. He was a co-editor of Intercultural Dialogue: Questions of Research, Theory and Practice, Routledge (2016), and of Travelling Languages: Culture, Communication and Translation in a Mobile World, Routledge (2014). He is the author of the article 'English as a Lingua Franca: An Immanent Critique,' Applied Linguistics, 35(5), (2014), and with William Simpson, of 'Fetishism and the Language Commodity: A Materialist Critique,' Language Sciences (2018). He is currently completing a book on Global English and Political Economy, also for Routledge.

John Gray is Reader in Languages in Education at UCL Institute of Education, University College London. He has published in Applied Linguistics, ELT Journal, Language Teaching Research and the Journal of Multilingual and Multicultural Development. He is the co-author of Neoliberalism and Applied Linguistics (2012), written with David Block and Marnie Holborow, and of Social Interaction and English Language Teacher Identity (2018), co-authored with Tom Morton. From 2013-15 he was a grant holder for the ESRCfunded seminar series Queering ESOL: towards a cultural politics of LGBT issues in the ESOL classroom (ES/L001012). He is currently editing a special issue of Gender and Language with Melanie Cooke on 'Intersectionality, Language and Queer Lives'.

\section{References}

Althusser, L. (1971). Lenin and Philosophy. New York: Monthly Review Press. 
Becker, G. ([1964] 1993). Human Capital: A Theoretical and Empirical Analysis, with Special Reference to Education (3rd ed.). Chicago: Chicago University Press.

Bernstein, B. (1990). The Structuring of Pedagogic Discourse. London: Routledge.

Bergfeld, M. (2018). 'Do you believe in life after work?' The University and College Union strike in Britain. Transfer: European Review of Labour and Research, 24 (2), pp. 233-236.

Bhaskar, R. (1986). Scientific Realism and Human Emancipation. London: Verso.

Bhaskar, R. (2008). A Realist Theory of Science. London: Verso.

Bhaskar, R. (2016). Enlightened Common Sense: The Philosophy of Critical Realism. London: Verso.

Block, D. (2017). Political Economy in Applied Linguistics Research. Language Teaching, 50(1), 32-64.

Block, D. (2018). Political Economy and Sociolinguistics: Neoliberalism, Inequality and Social Class. London: Bloomsbury.

Block, D., Gray, J., \& Holborow, M. (2012). Neoliberalism and Applied Linguistics. London: Routledge.

Boltanski, L. \& E. Chiapello. (2006). The New Spirit of Capitalism, London: Verso.

Bourdieu, P. (1998, December). Utopia of Endless Exploitation: The Essence of Neoliberalism. Le Monde diplomatique. Retrieved from https://mondediplo.com/1998/12/08bourdieu

Brenner, N. J., Peck, J. \& N. Theodore (2010). Variegated Neoliberalization: Geographies, Modalities, Pathways. Global Networks, 10, 182-222.

Chouliaraki, L., \& Fairclough, N. (1999). Discourse in Late Modernity: Rethinking Critical Discourse Analysis. Edinburgh: Edinburgh University Press.

Chun, C. (2017). The Discourses of Capitalism: Everyday Economists and the Production of Common Sense. Abingdon: Routledge.

Collini, S. (2012). What Are Universities For? London: Penguin.

Collini. S. (2017). Speaking of Universities. London: Verso.

Cook, G. (2012). British Applied Linguistics. Applied Linguistics Review, 3(1), 25-45.

Crouch, C. (2011). The Strange Non-death of Neoliberalism. Cambridge: Polity Press.

Dardot, P. \& C. Laval (2013). The New Way of the World: On Neoliberal Society. London: Verso.

Duménil, G. \& D. Lévy (2011). The Crisis of Neoliberalism. Cambridge, MA: Harvard University Press.

Fairclough, N. (1993). Critical Discourse Analysis and the Marketization of Public Discourse: the Universities. Discourse \& Society, 4(2), 133-168.

Fairclough, N. (2003). Analysing Discourse: Textual Analysis for Social Research. London: Routledge.

Fairclough, N. (2005). Critical Discourse Analysis in Transdisciplinary Research. In R. Wodak \& P. Chilton (Eds.), A New Agenda in (Critical) Discourse Analysis. (pp. 53-69). Amsterdam: John Benjamins.

Fairclough, N. ([2004] 2010). A Dialectical-relational Approach to Critical Discourse Analysis in Social Research. In N. Fairclough (Ed.), Critical Discourse Analysis: The Critical Study of Language (pp. 230254). London: Longman.

Fairclough, N. (2012). Critical Discourse Analysis. In J. P. Gee \& M. Handford (Eds.), The Routledge Handbook of Discourse Analysis (pp. 9-20). London: Routledge.

Fairclough, N. (2015). Language and Power. London: Routledge.

Fairclough, N., Jessop, B., \& Sayer, A. ([2004] 2010). Critical Realism and Semiosis. In N. Fairclough (Ed.), Critical Discourse Analysis: The Critical Study of Language (pp. 202-222). London: Longman. 
Foucault, M. ([1982] 1988). Technologies of the self. In H. Martin, H. Gutman, \& P. H. Hutton (Eds.), Technologies of the Self: A Seminar with Michel Foucault (pp. 16-49). Amherst: The University of Massachusetts Press.

Foucault, M. ([1978-79] 2008). The Birth of Biopolitics: Lectures at the Collège de France 1978-1979. New York: Palgrave Macmillan.

Gottschalk, M. (2015). The Prison State and the Lockdown of American Politics. Princeton, NJ: Princeton University Press.

Gramsci, A. (1971). Selections from Prison Notebooks. London: Lawrence and Wishart.

Habermas, J. (1984). The Theory of Communicative Action: Reason and the Rationalization of Society: Volume 1. London Heinemann.

Hall, S. (1990). Encoding/decoding. In S. Hall, D. Hobson, A. Lowe, \& P. Willis (Eds.), Culture, Media, Language (pp. 128-138). London: Unwin Hyman.

Hall, S., Massey, D., \& Rustin, M. (2013). After Neoliberalism? The Kilburn Manifesto. Soundings. Retrieved from https://www.Iwbooks.co.uk/sites/default/files/s53_02hall_massey_rustin.pdf

Harvey, D. (1996). Justice, Nature and the Geography of Difference. Oxford: Blackwell.

Harvey, D. (2005). A Brief History of Neoliberalism. Oxford: Oxford University Press.

Harvey, D. (2010). The Enigma of Capital: and the Crises of Capitalism. London: Profile Books.

Harvey, D. (2014). Seventeen Contradictions and the End of Capitalism. London: Profile Books.

Hayek, F. A. ([1944] 2001). The Road to Serfdom. London: Routledge.

HEFCE (2016). Consultation on the Second Research Excellence Framework (HEFCE, December 2016/36)

Retrieved from http://www.hefce.ac.uk/pubs/year/2016/201636/

Holborow, M. (2007). Language, ideology and neoliberalism. Journal of Language and Politics 6, 51-73.

Holborow, M. (2012). What is neoliberalism? Discourse, Ideology and the Real World. In D. Block, J. Gray, \&

M. Holborow (Eds.), Neoliberalism and Applied Linguistics (pp. 33-55). London: Routledge.

Holborow, M. (2015). Language and Neoliberalism. London: Routledge.

Holmwood, J., Hickey, T., Cohen, R. \& S. Wallis (2016) In Defense of Public Higher Education: Knowledge for a Successful Society. Convention for Higher Education: Sage.

Marx, K. ([1867] 1976). Capital: A Critique of Political Economy. Volume 1. Harmondsworth: Penguin.

Mirowski, P. (2013). Never Let a Serious Crisis Go to Waste: How Neoliberalism Survived the Financial Meltdown. London: Verso.

O'Regan, J. P., \& Betzel, A. (2016). Critical Discourse Analysis: A Sample Study of Extremism. In H. Zhu (Ed.), Research Methods in Intercultural Communication. Blackwell Guides to Research Methods in Applied Linguistics (pp. 281-296). London: Blackwell.

Panitch, L., \& Gindin, S. (2012). The Making of Global Capitalism: The Political Economy of Global Empire. London: Verso.

Peck, J. (2010). Constructions of Neoliberal Reason. Oxford: Oxford University Press.

Phillipson, R. (2008). The Linguistic Imperialism of Neoliberal Empire. Critical Inquiry in Language Studies, 5(1), 1-43.

REF 2014 (REF 02.2011). Assessment Framework and Guidance on Submissions. Retrieved from https://www.ref.ac.uk/2014/pubs/2011-02/

REF 2014 (REF 01.2012). Panel Criteria and Working Methods. Retrieved from https://www.ref.ac.uk/2014/pubs/2012-01/ 
REF 2021 (REF 2017/01) Initial Decisions on the Research Excellence Framework. Retrieved from http://www.ref.ac.uk/publications/2017/initialdecisionsontheresearchexcellenceframework2021.ht $\mathrm{ml}$

Robertson, S. L. (2002). Changing Governance/Changing Equality?: understanding the politics of publicprivate-partnerships in education in Europe. In European Science Foundation Exploratory Workshop: Globalisation, Education Restructuring and Social Cohesion in Europe, Barcelona, Spain. Retrieved from http://www.ieps.org.uk/media/1051/dec04.pdf

Sayer, D. (2015). Rank Hypocrisies: The Insult of The REF. Sage: London.

Stedman Jones, D. (2012). Masters of the Universe: Hayek, Friedman, and the Birth of Neoliberal Politics. Princeton \& Oxford: Princeton University Press.

Stern Review (2016). Building on Success and Learning from Experience: An Independent Review of the Research Excellence Framework. July 2016. Retrieved from https://www.gov.uk/government/publications/research-excellence-framework-review

Technopolis (2016). Synthesis of responses submitted to the REF Review Call for Evidence and follow-up interviews. Retrieved from https://www.gov.uk/government/publications/research-excellenceframework-review-summary-of-views

Wacquant, L. (2012). 'Three steps to a historical anthropology of actually existing neoliberalism'. Social Anthropology/Anthropologie Sociale, 20(1): 66-79.

Warner, M. (2014). Diary. London Review of Books, 36(17), $42-43$.

Warner, M. (2015). Learning My Lesson. London Review of Books, 37(6), 8-14.

Weber, M. ([1919] 1994). Weber: Political Writings, edited by Peter Lassman (Trans. Ronald Speirs). Cambridge: Cambridge University Press.

Zotzmann, K., \& O'Regan, J. P. (2016). Critical Discourse Analysis and Identity. In S. Preece (Ed.), The Routledge Handbook of Language and Identity (pp. 113-128). London: Routledge. 